\title{
Evaluation of Wind Resource Potential in Mountainous Region: A Case Study of Mandara Mountains
}

\author{
D. W. Medugu ${ }^{1}$, A. S. Umar ${ }^{1}$, J. Waida ${ }^{2}$
}

${ }^{1}$ Department of Pure and Applied Physics,Adamawa State University, Mubi

${ }^{2}$ Department of Integrated Science,Kashim Ibrahim College of Education, Maiduguri

\begin{abstract}
This study analyzed the evaluation of wind resource potential available at Mubi and Gwoza Northeastern Nigeria; and Guider and Mokolo far North Cameroon stations, respectively selected in Mandara Mountains covering period of six years (2011 to 2016). At all stations the overall maximum mean annual wind speed of $2.82 \mathrm{~m} / \mathrm{s}$ was found at Guider in 2015 and the minimum of $2.20 \mathrm{~m} / \mathrm{s}$ at Gwoza in 2012. The occurrences of annual mean wind speed of $2.82 \mathrm{~m} / \mathrm{s}$ was observed in 2015 at Guider reflecting a higher Weibull shape of 10.44 and scale $2.96 \mathrm{~m} / \mathrm{s}$ parameter, respectively. They were respectively observed in 2012 in Gwaza as $2.20 \mathrm{~m} / \mathrm{s}, 6.34$ and $2.36 \mathrm{~m} / \mathrm{s}$, while others stations are moderate. The annual Wind Power Density (WPD) potential at all stations varies between $7.15-14.25 \mathrm{~W} / \mathrm{m}^{2}$ while others are moderate. However, it was observed from this evaluation, that Mandara Mountain is a poor wind power potential site based on the International classification, with the highest value being Guider station. Therefore, the site is applicable for wind energy exploitation in small scale.
\end{abstract}

Keywords: Wind Resource, Wind Speed, Weibull Shape, Power Density, Mandara Mountains

\section{Introduction}

Wind can be defined as air in motion. People have learned how to use its resource for their economics need, which include energy production. Conversely, with increase in global warming, the warmed air causes uneven distribution of heat above the earth's surface, enhancing wind source by convection, thereby driven increase in wind speed circulation. Wind flow patterns arising on the Mountains regions are attractive in nature, to the extent that is available for 24 hours, irrespective of there being a device to intercept its flows, which have great potentials for energy productions.

Wind turbines and wind farms are being deployed in areas of increasing topographic complexity (Parvu, 2013). Mountains cover 25\% of the world's land surface, and are home to about $10 \%$ of its population, most of whom depend on mountain resource for their livelihoods (ARCOS Network, 2017). In addition, uneven ground features can cause a wide range of local wind flow effects (Tin and Robert, 2015). With the flow moving to the top hill, the blockage effect will decrease gradually and finally disappear when the flow moves on to the top hill. At the same time, the speed - up effect will increase continuously and reach to maximum (Tian et al, 2015). A steady supply of reasonably strong wind is necessary requirement for utilizing the power in the wind (Chaudhry, 2007).

However, two African countries, i.e., Cameroon and Nigeria, have vast potentials, but currently are lagging behind in wind energy development (Abdullahi et al, 2013). Detailed wind speed measurements and data carried out in Nigeria in some hilly and coastal areas shown an excellent wind potential for implementation of wind farms in those areas (Ayoade, 2012).

This study is aimed at evaluating the potential of wind resource in Mandara Mountain region with the emphasis of analyzing the mean wind speed and estimating the potential wind power density available at the stations.

\section{Materials and Methods}

Wind data used for this evaluation were those at $10 \mathrm{~m}$ height above the ground level for Mubi and Gwoza in Nigeria; and Guider and Mokolo in Cameroon captured with satellite covering period from 2011 to 2016 obtained from meteoblue AG. Basel, Schweiz/ Switzerland

\section{Study Area}

Variously defined by authors, the Mandara Mountains are generally agreed to extend on both sides of the Nigeria-Cameroon border from the

This article is published under the terms of the Creative Commons Attribution License 4.0 Author(s) retain the copyright of this article. Publication rights with Alkhaer Publications. Published at: http://www.ijsciences.com/pub/issue/2020-04/

DOI: 10.18483/ijSci.2313; Online ISSN: 2305-3925; Print ISSN: 2410-4477 
Benue-Kebbi valley north to the Zelidva hills, some $130 \mathrm{Km}$ south of Lake Chad (David, 2012). The highest elevation is the summit of mount Oupay, at $1494 \mathrm{~m}$ (4900ft) above sea level. The Mandara Mountains were formed millions of years ago when a continental plate of basement rock deep beneath the African continent rose up, fragmenting and splitting as it was pushed to the surface (Sheffel and Wernet, 1980). Depending on altitude and region, the average annual temperature is $23.9^{0} \mathrm{C}$ varies by $1.2^{0} \mathrm{C}$ and the annual average precipitation is $1629 \mathrm{~mm}$ varies by $102 \mathrm{~mm}$.
Mandara Mountains $\left(10^{0} 53^{\prime} \mathrm{N} 13^{\circ} 47^{\prime} \mathrm{E} / 10.883^{0}\right.$ $13.783^{\circ}$ E) settlements are characteristically identified with rural in nature, predominated by mud building, un-tarred roads and has limited supply of modern energy (Renewable energy), where most of them relies on wood for household use. Most people there are farmers in which their principal crop is sorghum. They also engage in small scale industrial commercial activities such as black smiting, tourist activities, thatch roofing and petty trading. There major towns are Mokolo and Maroua in Cameroon; and Mubi and Madagali in Nigeria.

Figure 1: Shows the Google map of Mandara Mountains with different elevated height indicated by color in meter, $\mathrm{m}$ and white indicating the stations.

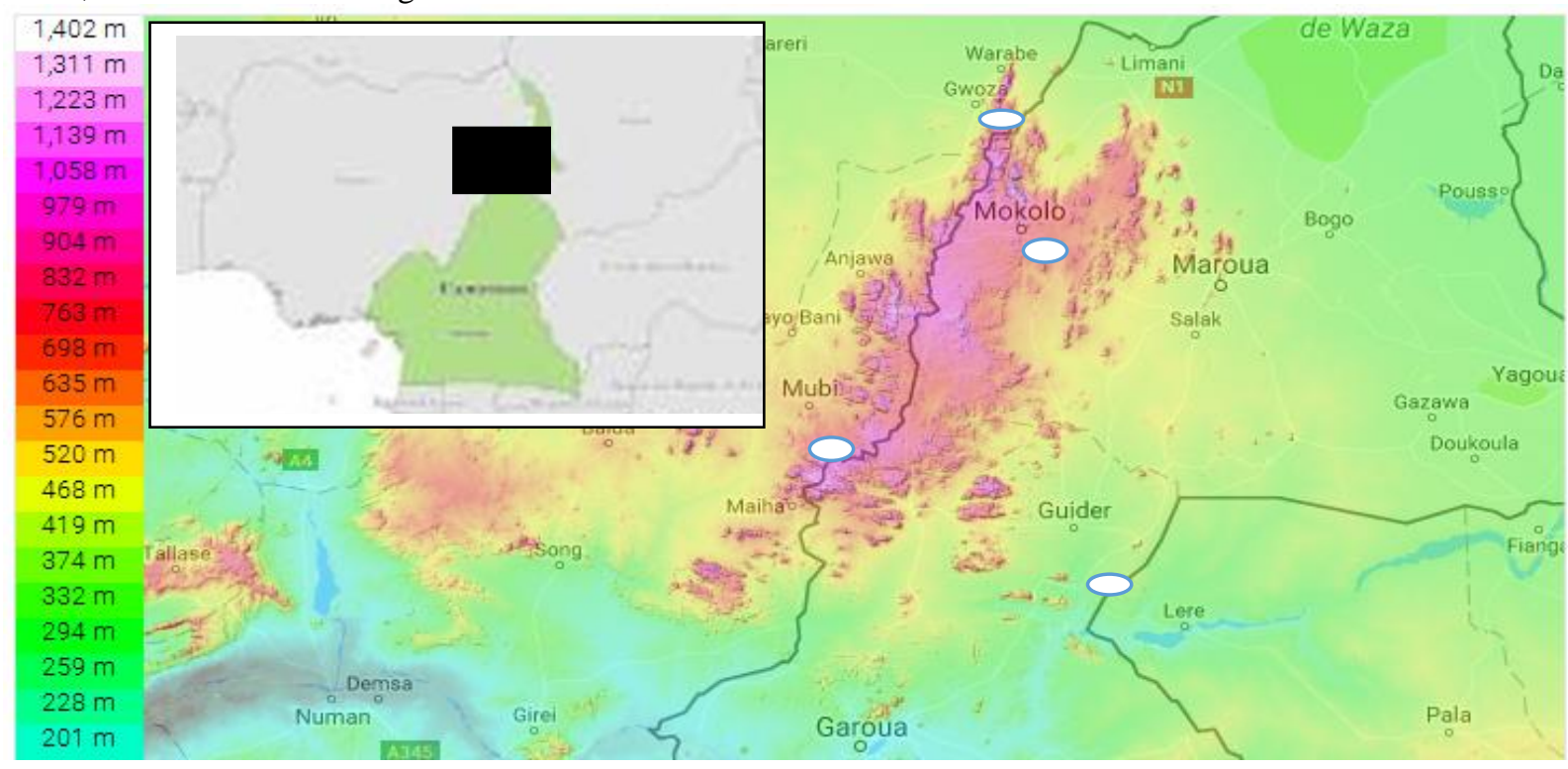

\section{Empirical Background}

Various statistical tools have been used for the analysis of wind speed data. Among several tools, the two parameter Weibull distribution is internationally and extensively used function for analyzing measured wind speed data in a given location over a given time period. Hence, the continuously recorded wind speed values and the standard deviation can be calculated from the available monthly wind speed data using equations (1) and (2) as shown (Akpinar and Akpinar, 2004; Ahmed, 2013).

$\mathrm{V}_{\mathrm{m}}=\frac{1}{N}\left[\sum_{i=1}^{n} V_{i}\right]$
$\sigma=\left[\frac{1}{N-1} \sum_{i=0}^{n}\left(V_{i}-V_{m}\right)^{2}\right]^{\frac{1}{2}}$

Where,

$\mathrm{V}_{\mathrm{m}}(\mathrm{m} / \mathrm{s})$ is the wind mean speed, $\mathrm{N}$ is the number of months in the period considered, $\sigma$ is the standard deviation, $\mathrm{V}_{\mathrm{i}}$ is the given wind speed.
Weibull distribution is a two parameters function characterized by scale parameter $\mathrm{c}(\mathrm{m} / \mathrm{s})$ and shape parameter $\mathrm{k}$ (dimensionless) where probability of occurrence of certain velocity is given by (Weibull, 1951; Ahmed, 2013; Ayush, 2016).

$$
\mathrm{F}_{\mathrm{W}}=\left(\frac{k}{c}\right)\left(\frac{k}{c}\right)^{k-1} \exp \left[-\left(\frac{v}{c}\right)^{k}\right]
$$

Shape parameter, $\mathrm{k}$ and scale parameter, $\mathrm{c}$, have been proposed to estimate using many methods. Graphic method, Maximum likelihood method and Moment methods are commonly used to estimate Weibull parameters (Ayush, 2016). The popular methods include method of moment, often used in a wind atlas (Fisher, 1993). The scale parameter, c, further indicate how windy a location under consideration is, whereas the shape parameter, $\mathrm{k}$, indicates how peaked the wind distribution is (Keyhani, 2010; Ajayi et al, 2013).

The Empirical method is the special case of the moment method, where the parameters $\mathrm{k}$ and $\mathrm{c}$ are defined by using average wind speed and standard 
deviation by following equations (Akdag and Ali, 2009; Kengne et al, 2016).

$$
\begin{aligned}
& \mathrm{k}=\left(\frac{\sigma}{v}\right)^{-1.089} \\
& \mathrm{c}=\frac{v}{\Gamma\left(1+\frac{1}{k}\right)}
\end{aligned}
$$

The higher the value of $\mathrm{k}$, the shaper the curve and the lower the value of $\mathrm{k}$, the flatter and evenly distributed wind speed curves (Justus \& Mikhail, 1976).

Where;

$$
\mathrm{P}_{\mathrm{W}}=\frac{1}{2} \rho C^{3} \Gamma\left[1+\frac{3}{K}\right]
$$

$\mathrm{P}_{\mathrm{W}}$ is Weibull power, $\mathrm{C}$ is scale factor $(\mathrm{m} / \mathrm{s})$.

$\Gamma(x)$ is gamma function (Abdullahi et al, 2013) which is given as,

$$
\Gamma(\mathrm{x})=\int_{0}^{\alpha} t^{1-x} e^{t} d t
$$

Where;

$\mathrm{x}$ is complex number, $\mathrm{t}$ is natural number.

\section{Analysis of Weibull Probability Density Function (WPDF)}

Daily mean wind speed was used in evaluating monthly mean wind speed to estimate of scale, c, and shape parameters, $\mathrm{k}$, to generate WPDF. In method moments, yearly shape and scale parameters of the WDF were estimated from the mean wind speed and standard deviation of wind data by using equations (1) and (2) expressions respectively. With both $\mathrm{k}$ and $\mathrm{c}$ computed from equations (4) and (4) respectively. The Gamma function (natural logarithm) in equation (6) is used to narrow range of values in equation (7) to determined WPD.

\section{Estimation of Wind Power Density}

Although, wind speed analysis is useful, but wind power analysis is more relevant for determining energy production from wind turbines. Wind power density were considered as a better indicator of the wind resource evaluation. For this evaluation the density of air is assumed to be $1.225 \mathrm{~kg} / \mathrm{rn}^{3}$ at $10 \mathrm{~m}$ height, $15^{\circ} \mathrm{C}$ determine using equation (7) for available annual wind speed.

\section{Results and Discussions}

Table 1: Monthly mean wind speed values of Mubi from 2011-2015

\begin{tabular}{lllllllllllll}
\hline DATE & JAN & FEB & MAR & APR & MAY & JUN & JUL & AUG & SEP & OCT & NOV & DEC \\
\hline 2011 & 2.15 & 2.44 & 2.90 & 2.71 & 2.97 & 3.38 & 2.77 & 2.39 & 2.05 & 2.77 & 2.04 & 2.23 \\
2012 & 2.32 & 2.59 & 3.11 & 2.87 & 3.34 & 3.24 & 2.56 & 2.21 & 1.95 & 1.84 & 1.78 & 2.24 \\
2013 & 2.27 & 2.81 & 2.18 & 2.47 & 3.08 & 3.38 & 3.16 & 2.44 & 2.15 & 1.87 & 1.80 & 2.30 \\
2014 & 2.07 & 2.65 & 2.47 & 2.90 & 2.62 & 3.54 & 3.37 & 2.64 & 2.23 & 1.90 & 1.84 & 2.17 \\
2015 & 2.50 & 2.46 & 2.82 & 2.80 & 2.75 & 3.53 & 3.06 & 2.23 & 2.27 & 2.20 & 2.15 & 2.90 \\
\hline
\end{tabular}

Table 2: Monthly mean wind speed values of Mokolo from 2011-2015

\begin{tabular}{lllllllllllll}
\hline DATE & JAN & FEB & MAR & APR & MAY & JUN & JUL & AUG & SEP & OCT & NOV & DEC \\
\hline 2011 & 2.31 & 2.37 & 2.77 & 2.38 & 2.65 & 2.96 & 2.38 & 1.90 & 1.66 & 1.74 & 1.92 & 2.06 \\
2012 & 2.11 & 2.44 & 2.77 & 2.31 & 2.97 & 2.85 & 2.22 & 1.83 & 1.65 & 1.75 & 1.74 & 2.08 \\
2013 & 2.17 & 2.34 & 2.12 & 2.21 & 2.68 & 2.92 & 2.66 & 2.00 & 1.88 & 1.77 & 2.83 & 2.16 \\
2014 & 1.98 & 2.89 & 2.26 & 2.44 & 2.41 & 3.17 & 2.94 & 2.30 & 1.92 & 1.66 & 2.83 & 2.03 \\
2015 & 2.34 & 2.31 & 2.60 & 2.68 & 2.31 & 2.92 & 2.85 & 1.92 & 1.83 & 2.02 & 2.17 & 2.56 \\
\hline
\end{tabular}

Table 3: Monthly mean wind speed values of Guider from 2011-2015

\begin{tabular}{lllllllllllll}
\hline DATE & JAN & FEB & MAR & APR & MAY & JUN & JUL & AUG & SEP & OCT & NOV & DEC \\
\hline 2011 & 2.92 & 2.71 & 2.92 & 2.50 & 3.10 & 3.55 & 3.01 & 2.51 & 2.13 & 1.93 & 2.17 & 2.65 \\
2012 & 2.72 & 2.81 & 2.23 & 3.78 & 3.51 & 3.61 & 2.84 & 2.21 & 2.01 & 2.17 & 1.89 & 2.73 \\
2013 & 2.64 & 2.82 & 2.18 & 2.32 & 3.07 & 3.59 & 3.40 & 2.61 & 2.36 & 1.86 & 1.96 \\
2014 & 2.52 & 2.89 & 2.53 & 2.74 & 2.64 & 3.72 & 3.62 & 2.69 & 2.38 & 1.93 & 1.88 \\
2015 & 2.94 & 2.68 & 2.85 & 2.83 & 2.77 & 3.90 & 3.42 & 2.47 & 2.75 & 2.43 & 2.41 & 2.38 \\
\hline
\end{tabular}

Table 4: Monthly mean wind speed values of Gwoza from 2011-2015

\begin{tabular}{lllllllllllll}
\hline DATE & JAN & FEB & MAR & APR & MAY & JUN & JUL & AUG & SEP & OCT & NOV & DEC \\
\hline 2011 & 2.21 & 2.30 & 2.56 & 2.33 & 2.57 & 2.89 & 2.47 & 1.90 & 1.71 & 1.75 & 1.89 & 1.99 \\
2012 & 2.08 & 2.34 & 2.63 & 2.25 & 2.78 & 2.85 & 2.31 & 1.95 & 1.70 & 1.69 & 1.73 & 2.14 \\
2013 & 2.00 & 2.26 & 2.66 & 2.23 & 2.57 & 2.85 & 2.73 & 2.04 & 1.93 & 1.78 & 2.82 & 2.30 \\
2014 & 1.93 & 2.28 & 2.20 & 2.27 & 2.30 & 2.97 & 2.95 & 2.32 & 1.99 & 1.67 & 1.86 & 1.97 \\
2015 & 2.31 & 2.24 & 2.52 & 2.60 & 2.24 & 2.84 & 2.62 & 2.07 & 2.00 & 2.08 & 2.12 & 2.41 \\
\hline
\end{tabular}


Figure 2: Mubi five years monthly mean wind speed

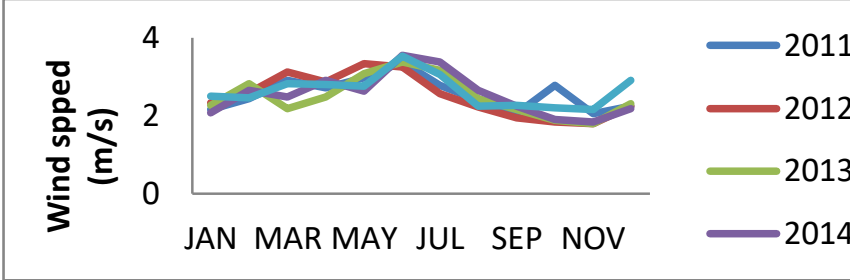

Figure 3: Mokolo Five years monthly mean wind speed

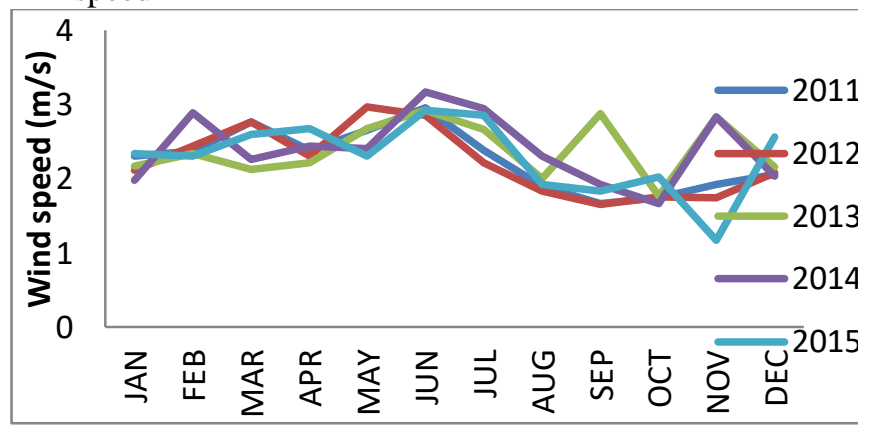

Figure 4: Guider five years monthly mean wind speed

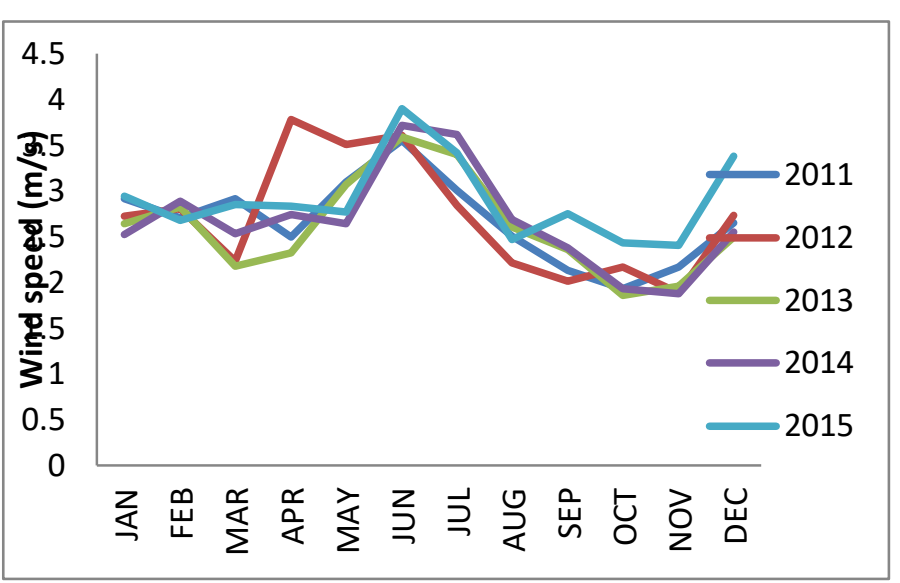

Figure 5: Gwoza five years monthly mean wind speed

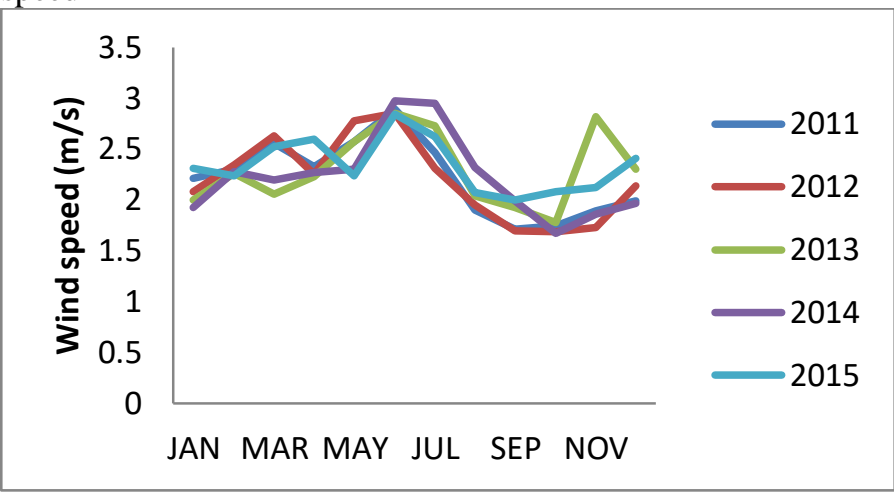

Table 5: Distribution of annualy $V_{m}(\mathrm{~m} / \mathrm{s}), \sigma, \mathrm{k}, \mathrm{c}$ and $F_{W}\left(\mathrm{~W} / \mathrm{m}^{2}\right)$

\begin{tabular}{lllllll}
\hline Stations & Years & $\boldsymbol{V}_{\boldsymbol{m}}(\mathrm{m} / \mathrm{s})$ & $\boldsymbol{\sigma}$ & $\mathbf{k}$ & $\mathbf{c}(\mathrm{m} / \mathrm{s})$ & $\boldsymbol{F}_{\boldsymbol{W}}\left(\mathrm{W} / \mathrm{m}^{2}\right)$ \\
\hline Mubi & 2011 & 2.60 & 0.40 & 7.74 & 2.77 & 11.49 \\
& 2012 & 2.50 & 0.54 & 5.30 & 2.71 & 10.78 \\
& 2013 & 2.49 & 0.51 & 5.63 & 2.69 & 10.61 \\
& 2014 & 2.53 & 0.53 & 5.38 & 2.74 & 11.25 \\
& 2015 & 2.64 & 0.42 & 7.50 & 2.81 & 12.07 \\
\hline Mokolo & 2011 & 2.26 & 0.41 & 6.39 & 2.43 & 7.76 \\
& 2012 & 2.23 & 0.46 & 5.65 & 2.41 & 7.61 \\
& 2013 & 2.30 & 0.38 & 7.17 & 2.46 & 8.04 \\
& 2014 & 2.32 & 0.47 & 5.69 & 2.51 & 8.56 \\
Guider & 2015 & 2.37 & 0.35 & 6.66 & 2.54 & 8.89 \\
& 2011 & 2.68 & 0.44 & 6.81 & 2.87 & 13.07 \\
& 2012 & 2.71 & 0.52 & 4.79 & 2.96 & 14.22 \\
& 2013 & 2.61 & 0.49 & 5.59 & 2.82 & 12.24 \\
& 2014 & 2.67 & 0.56 & 5.55 & 2.89 & 13.14 \\
\hline Gwoza & 2015 & 2.82 & 0.62 & 10.44 & 2.96 & 14.25 \\
& 2011 & 2.21 & 0.39 & 6.99 & 2.36 & 7.15 \\
& 2012 & 2.20 & 0.49 & 6.34 & 2.36 & 7.16 \\
& 2013 & 2.30 & 0.33 & 7.44 & 2.45 & 8.00 \\
& 2014 & 2.23 & 0.42 & 6.52 & 2.39 & 7.43 \\
\end{tabular}


Figure 6: WPDF plot from 2011-2015 for Mubi

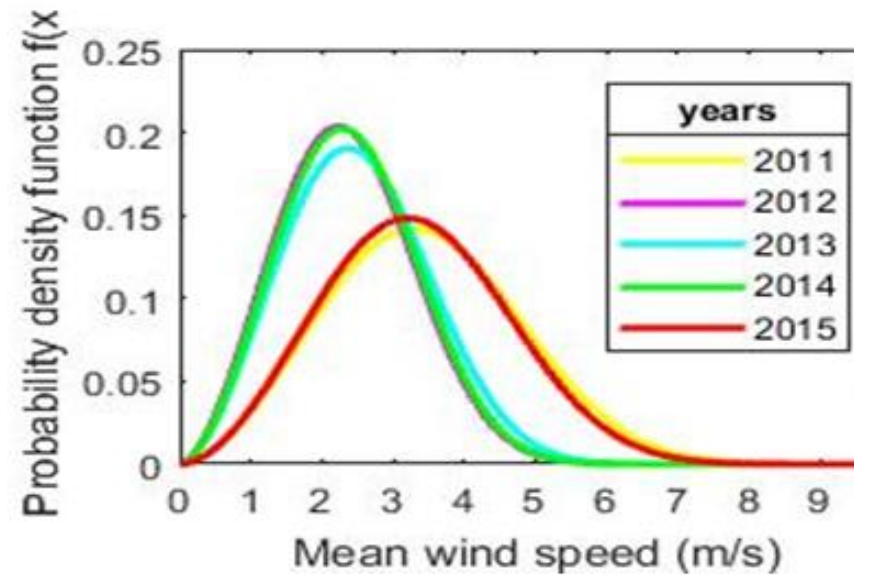

Figure 7: WPDF plot from 2011-2015 for Mokolo



Figure 8: WPDF plot from 2011-2015 for Guider

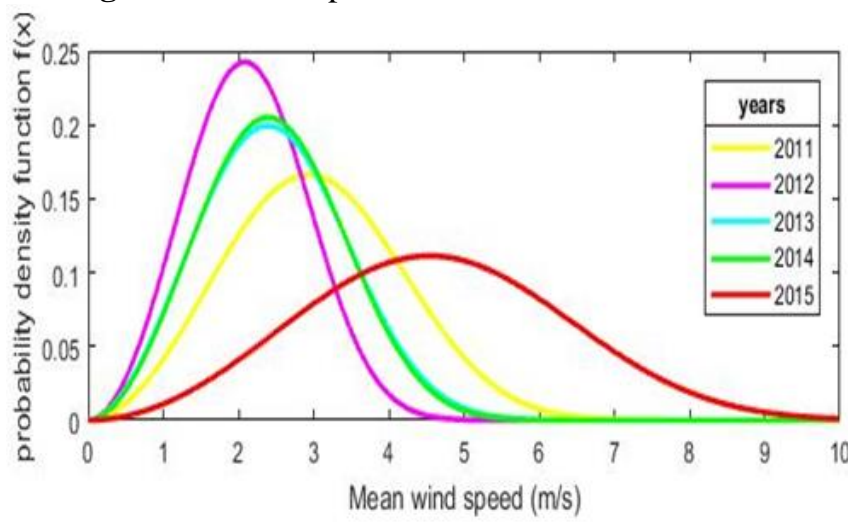

Figure 9: WPDF plot from 2011-2015 for Gwoza

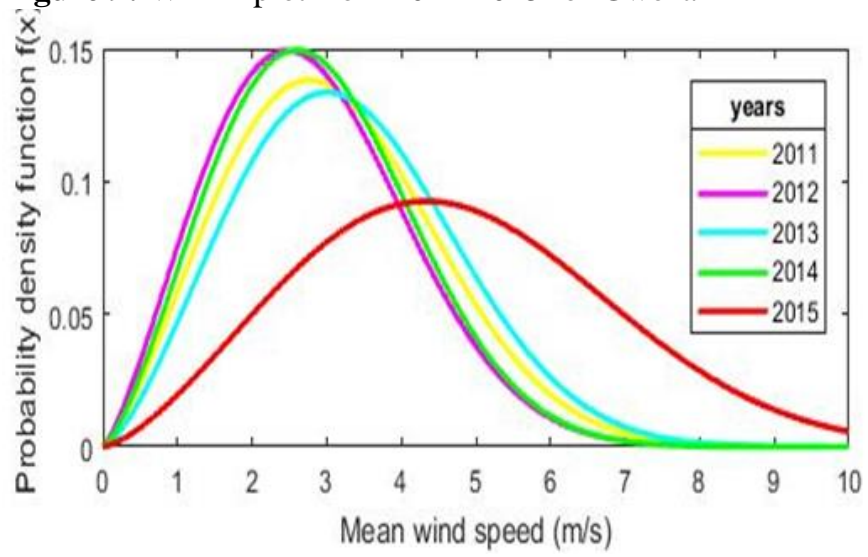

Figure 10: Distribution of yearly wind power density Distribution of yearly wind power density

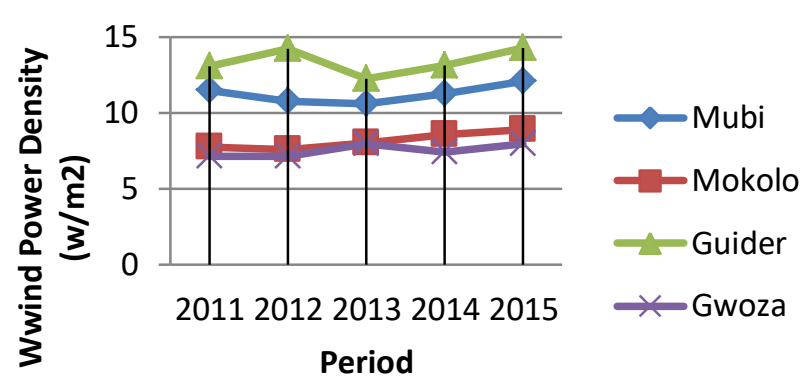

\section{Wind Speed}

Considering Mubi station shown in Fig. 2 obtained from Table 1, which is the average wind speed of the entire five years, highest were recorded in June with wind speed values ranging from 3.24 to 3.57 $\mathrm{m} / \mathrm{s}$ and it is lowest in November ranging from 1.78 to $2.15 \mathrm{~m} / \mathrm{s}$. Maximum deviations were observed between the months of September to November with minimum values in June and September, while others months were moderate.

Considering Mokolo station shown in Fig. 3 obtained from Table 2, which is the average wind speed of the entire five years, highest were recorded in June with wind speed values ranging from 2.85 to $3.17 \mathrm{~m} / \mathrm{s}$ and it is lowest in September ranging between 1.66 to $2.02 \mathrm{~m} / \mathrm{s}$. Maximum deviations were observed between the months of October to December with minimum values in June and August, while others months were moderate.

Considering Guider station shown in Fig. 4 obtained from Table 3, which is the average wind speed of the entire five years, highest were recorded in June with wind speed values ranging from 3.55 to $3.90 \mathrm{~m} / \mathrm{s}$ and it is lowest in the months on October ranging between 1.86 to $2.42 \mathrm{~m} / \mathrm{s}$. Maximum deviations was observed between the 
months of March to June, while others months were moderate.

Considering Gwoza station shown in Fig. 5 obtained from Table 4, which is the average wind speed of the entire five years, highest were recorded in June with wind speed values ranging from 2.84 to $2.97 \mathrm{~m} / \mathrm{s}$ and it is lowest in the months of October ranging from 1.67 to $2.08 \mathrm{~m} / \mathrm{s}$. Maximum deviation were observed between the months of October to December, while others months were moderate.

\section{Weibull Probability Density Function}

From the results obtained in Fig. 6 - 9 plotted from Table 5 for the annual variations of WPDF parameters and its wind speed. The shape factor $(\mathrm{k})$ for Mubi station varies in between $5.30-7.74$, the scale factor (c) varies between $2.69-2.81 \mathrm{~m} / \mathrm{s}$ and wind speed varies between $2.50-2.64 \mathrm{~m} / \mathrm{s}$. The shape factor $(\mathrm{k})$ for Mokolo varies in between 5.657.17, the scale factor (c) varies between 2.41$2.54 \mathrm{~m} / \mathrm{s}$ and the wind speed varies from 2.23 $2.37 \mathrm{~m} / \mathrm{s}$. The shape factor $(\mathrm{k})$ for Guider varies in between 4.79-10.44, the scale factor (c) varies between $2.82-2.96 \mathrm{~m} / \mathrm{s}$ and the wind speed varies from $2.61-2.82 \mathrm{~m} / \mathrm{s}$. The shape factor $(\mathrm{k})$ for Gwoza varies in between $6.34-10.74$, the scale factor (c) varies between $2.36-2.45 \mathrm{~m} / \mathrm{s}$ and the wind speed varies from $2.20-2.34 \mathrm{~m} / \mathrm{s}$. This indicates the peak of WPDF of wind speed possibly prevails at a location. That is, simply it provides the most frequently occurring wind speed for a given wind probability distribution. Therefore, large deviation was observed to be in Guider compared to Mubi and Gwoza which are moderates and it is less in Mokolo.

\section{Wind Power Density}

From Fig. 10 plotted from Table 5, the annuals wind power density for Mandara mountain at $10 \mathrm{~m}$ height above the ground levels from 2011 to 2016 were observed to be highest in Guider varies between about $13.07 \mathrm{~W} / \mathrm{m}^{2}$ to $14.25 \mathrm{~W} / \mathrm{m}^{2}$. The lowest was observed at Gwoza varies between $7.15 \mathrm{~W} / \mathrm{m}^{2}$ to 8.0 $\mathrm{W} / \mathrm{m}^{2}$, with Mubi and Mokolo being 10.61 to 12.07 $\mathrm{W} / \mathrm{m}^{2}$ and 7.61 to $8.89 \mathrm{~W} / \mathrm{m}^{2}$. Mean well that the range of deviations are stable at Mokolo, where Guider were unstable while Mubi and Gwoza are intermediates. Hence, it can be seen from tables that the favorable locations for wind power generation on Mandata Mountain, is Guider with large values of WPDF among all stations.

The power density level is rather rated poor for economical large-scale power production, lying in Class 1 according to the US NREL wind power density classification (Wind Power Class, 2014). These results obtained may be suitable for rural applications such as water pumping and/or even power generation using special wind turbines with low cut-in speeds.

\section{Conclusion}

The Conclusions drawn from this study shows that the maximum and minimum annual mean wind speed for Mubi were observed to be $2.64 \mathrm{~m} / \mathrm{s}$ and $2.49 \mathrm{~m} / \mathrm{s}$ respectively. For Mokolo, they were respectively $2.37 \mathrm{~m} / \mathrm{s}$ and $2.23 \mathrm{~m} / \mathrm{s}$. For Guider they were $2.82 \mathrm{~m} / \mathrm{s}$ and $2.61 \mathrm{~m} / \mathrm{s}$ respectively. $2.34 \mathrm{~m} / \mathrm{s}$ and $2.20 \mathrm{~m} / \mathrm{s}$ were respectively observed for Gwoza. Also shows a similar trend to seasonal variations for all four station where wind speed increases from January and reaches its peak value in June in dry season, then its decreases from July to October as these months are susceptible to heavy rainfall in region, but again rises gradually till December. That is, maximum and minimum mean wind speed in different months belonged to June and October for all stations. These occurrences of annual mean wind speed of $2.82 \mathrm{~m} / \mathrm{s}$ was observed in 2015 at Guider reflecting a higher Weibull shape of 10.44 and scale $2.96 \mathrm{~m} / \mathrm{s}$ parameter, respectively. They were respectively observed in 2012 in Gwaza as $2.20 \mathrm{~m} / \mathrm{s}$, 6.34 and $2.36 \mathrm{~m} / \mathrm{s}$, while others stations are moderate. The annual Wind Power Density (WPD) potential at all stations varies between $7.15-14.25 \mathrm{~W} / \mathrm{m}^{2}$. However, it was observed that Mandara Mountain is a poor wind power potential site based on the International classification, with the highest value being Guider station. Therefore, the site is applicable for wind energy exploitation in small scale.

\section{Acknowledgement}

We express our sincere thanks with deep sense of gratitude to Mrs. Anne Gretsch for her assistance and the entire wonderful staffs of meteoblue AG. Basel, Schweiz/ Switzerland for providing data to make this study possible.

\section{References}

1. Abdullahi, A., Adisa, A. B. and Dandakuta, H. (2013): An evaluation of wind energy potential in the Northern and Southern region of Nigeria on the basis of Weibull and Rayleigh models. American Journal of Energy Engineering . Vol.1(3).pp.37-42. Doi:10.11648.ajee.20130103.11.

2. Ahmed, S. A. (2013): Comparative study of four models for estimating Weibull parameters for Habubja. Iraq. International Journal of Physical Science. Vol.8: 186-192.

3. Ajayi, O. O., Fagbenle, R. O., Katunde, J., Samson, A. A., and Okeniyi, J. O. (2013): Wind profile characteristics and turbine performance analysis in Kano North-Westhern Nigeria. Instrumental Journal of Energy and Environmental Engineering. Vol. 3: 27

4. Akdag, S. A and Ali, D (2009): A new method to estimate Weibull parameters for wind energy applications. Energy Convers. Manag. 50:1761-1766.

5. Akpinar, K. E and Akpinar, S. (2004): Statistical analysis of wind energy potential on the basis of Weibull and Rayleigh distribution for Agin-Elazig, Turkey. Power and Energy. Vol. 218: 557-565.

6. ARCOS Network, (2017): African mountain: Water towers in need of attention. Society and science of sustainable 
mountains development. Available at; www.arcosnetwork.org. 2017 ).

7. Ayoade, F. A., Akinbulire, O. T. and Awosope, C.O.A (2012): Wind energy potential in Nigeria. International Electric Engineering Journal ( IEEJ ). Vol. 3(1): 565-601. ISSN:2078-2365.

8. Ayush, P. (2016): A statistical analysis of wind speed and power density based on Weibull and Rayleigh models of Jumla, Nepal. Energy and Power Engineering. Vol .8: 271282.

9. Chaudhry, Q. Z. (2007): An investigation on wind power potential of Ghoro-sindh, Pakistan journal of meteorology. Vol. 6(2)

10. David, N. (2012): Metals in Mandara Mountains Society and Culture. African World Press. 541 West Ingham Avenue | Suite B Trenton, New Jersey 08638.

11. Fisher, N. I. (1993): Statistical analysis of circular data. Cambridge University Press. Pp. 277.

12. Justus, C. G., \& Mikhail, A. (1976). Height variation of wind speed and wind distributions statistics.Geophysical Research Letters, Vol. 3(5): 261-264.

13. Kengne, S. E., Oumarou, H. and Nganhou, J. (2016): Modeling of characteristics of wind by Weibull distribution and estimation of wind energy in Douala, Littoral region of Cameroon. International Journal of Innovative, Research in
Science, Engineering, and Technology. Vol. 5(5): 66016609.

14. Keyhani, A., Ghasemi-Varnamkhasti, M., Khanali, M and Abbaszadeh, R. (2010): An assessment of wind energy potential as a power generation sorce in the capital of Iran, Tehran. Energy. Vol.35(1):188-201. https//doi.org/10./1016/j.enery.2009.09.009

15. Parvu, D. S. (2013): Experimental modeling of wind form topography and canopy. Electronic thesis at Department of civil and Environmental Engineering. University of Western Ontario, Canada. Available at: http://ir.lib.uwo.ca/etd.

16. Scheffel, R. L. and Wernert, S. J. (1980): Reader's digest natural wonders of the World. Pleasentville, N.Y. ISBN 0895-7708-73

17. Tian, W., Ozbay, A. and Hu, H. (2015): Terrain effects on characteristic of surface Swind and wind turbines wakes. $7^{\text {th }}$ International Conference on Fluid Mechanics, ICFM7. Procedia Engineering. Vol. 126: 542-548. Available at www. Sciencedirect.com.

18. Tin, O. and Robert, P. (2015): Small wind site assessment guidelines. Technical report. National Renewable Energy Laboratory ( NREL ). Available at www.nrel.gov/publications.

19. Weibull, W. (1951): A statistical distribution function of wide applicability. Journal of Applied Mechanics. Vol. 103: 293-29 